\title{
Pelatihan Pemamfaatan Pestisida alami Berbahan lokal untuk Pencegahan Vektor Demam Berdarah Dengue (DBD) di Kelurahan Kelapa Lima Kota Kupang
}

\author{
Julianty Almet ${ }^{1 *}$, Diana A Wuri², Meity M Laut ${ }^{3}$, Annytha I R Detha ${ }^{4}$ iD \\ 1,2,3,4 Fakultas Kedokteran Hewan, Universitas Nusa Cendana, Indonesia \\ *Corresponding author: yanti.almet@yahoo.com
}

\begin{abstract}
Abtrak
Kegiatan Pengabdian kepada Masyarakat telah dilaksanakan di Desa Kelapa Lima. Kegiatan ini bertujuan untuk memberikan informasi dan pengetahuan kepada masyarakat tentang bahaya penyakit demam berdarah dengue dan upaya pencegahannya melalui pemanfaatan potensi tanaman pengusir nyamuk. Tanaman pengusir nyamuk dapat ditemukan di pekarangan rumah sehingga masyarakat dapat menyediakan lahan di pekarangan rumahnya untuk menanam tanaman yang berpotensi sebagai pengusir nyamuk. Metode yang digunakan dalam kegiatan pengabdian ini berupa penyuluhan, pelatihan, dan pembudidayaan tanaman sebagai agen anti nyamuk penyebab penyakit demam berdarah dengue. Kesimpulan yang diperoleh adalah peningkatan pengetahuan pemahaman masyarakat tentang Demam Berdarah Dengue, peningkatan pemahaman masyarakat tentang bioekologi vektor penyebab demam berdarah dengue, pemanfaatan tumbuhan yang berpotensi sebagai pengusir nyamuk.
\end{abstract}

Kata Kunci: Demam Berdarah Dengue, Tanaman Pengusir Nyamuk

\section{Abstract}

Community Service Activities have been carried out in Kelapa Lima Village. This activity aims to provide information and knowledge to the public about the dangers of dengue hemorrhagic fever and its preventive measures through the use of potential mosquito repellent plants. Mosquito repellent plants can be found in the yard of the house so that the community can provide land in the yard of their house to plant these plants that have the potential to act as mosquito repellent. The method used in this service activity is in the form of counseling, training, and cultivating plants as an anti-mosquito agent that causes dengue hemorrhagic fever. The conclusion obtained is an increase in the knowledge of the public's understanding of Dengue Hemorrhagic Fever, an increase in public understanding of the bio-ecology of the vector that causes dengue hemorrhagic fever, utilizing plants that have the potential to act as mosquito repellents.

Keywords: Dengue Hemorrhagic Fever, Mosquito Repellent Plants

\section{Introduction}

Penyakit vektor borne diseases merupakan penyakit yang penularannya melalui vektor seperti Malaria, Filariasis (Almet et al., 2019, 2020; Karuppusamy et al., 2021), Japanese encephalitis (A. I. R. Detha \& L., 2016), termasuk Deman berdarah Dengue. Penyakit vector-borne diseases penyakit menular yang sulit dikendalikan yang bersifat kompleks (Braks et al., 2014; Dillon et al., 2016). Banyak cara yang sudah dilakukan untuk mengatasi penyakit ini namunpenyakit ini akan kembali muncul, khusunya pada daerah-

$\begin{array}{lll}\text { History: } & & \text { Publisher: Undiksha Press } \\ \text { Received } & \text { : 02 Januari } 2021 & \text { Licensed: This work is licensed under } \\ \text { Revised } & \text { : 09 Januari } 2021 & \text { a Creative Commons Attribution 3.0 License } \\ \text { Accepted } & : \text { 06 Februari } 2021 & \\ \text { Published } & : \text { :25 Februari } 2021 & \end{array}$


daerah yang menjadi habitanya serta daerah yang penghasilnya rendah (Ashepet et al., 2021). Selain kondisi lingkungan yang mengakitkan kembalinya berkembanganya penyakit yang disebabkan oleh vector adalah iklim. Suhu adalah faktor lingkungan yang mendorong resiko vector-penyakit bawaan (Dell et al., 2011) serta perkembangan parasit di dalam vector (Liu et al., 2017; Paaijmans et al., 2012). Salah satu daerah yang sering menjadi tempat berkembangnya vector-borne diseases adalah NTT.

Di wilayah Nusa Tenggara Timur, telah dilaporkan sejumlah penyakit zoonosis (A. Detha, 2014; A. Detha et al., 2015; A. I. R. Detha et al., 2018; Tamonob et al., 2019), termasuk diantaranya penyakit vektor borne diseases (penyakit tular vektor). Laporan kasus penderita DBD di Provinsi NTT pada tahun 2013 ditemukan kasus DBD sebanyak 2.986 kasus, pada tahun 2014 jumlah penderita DBD sebanyak 487 kasus, sedangkan pada tahun 2015 meningkat menjadi 665 kasus dengan Kota Kupang, Kabupaten Sikka dan Kabupaten Manggarai Barat menempati posisi tertinggi kasus terbanyak kejadian DBD (Dinas Kesehatan Provinsi Nusa Tenggara Timur, 2015). Angka kesakitan DBD di Kota Kupang tahun 2012 sampai dengan 2016 mengalami fluktuasi. Jumlah penderita DBD di Kota Kupang pada tahun 2012 sebanyak 867 kasus, menurun pada tahun 2014 menjadi 102 kasus, kemudian meningkat pada tahun 2016 menjadi 381 kasus, salah satu wilayah dengan jumlah kasus tertinggi Kecamatan Kelapa Lima sebanyak 67 kasus (Dinas Kesehatan Kota Kupang, 2016). Untuk mengatasi hal tersebut banyak cara yang sdah dilakukan. Salah satunya dengan menggunkan isektisida dalam mengendalikan serangga pembawa vector penyakit.

Pengendalian serangga vektor penyakit menggunakan insektisida sudah dilakukan sejak jaman dahulu oleh masyarakat. Saat ini banyak masyarakat menggunkan insektisida untuk mengatasi serangan serangga vector penyakit baik insektisda alami maupuan komersil (Fuadzy \& Yanuar, 2018). Masyarakat menggunakan insektisida karena praktis, ekonomis dan hasilnya cepat menurunkan populasi (Sutarto \& Syani, 2018). Namun kejadian kasus DBD di Kota Kupang setiap tahun terus mengalami fluktuasi sementara penggunaan insektisida untuk pengendalian vektor masih terus dilakukan. Menurut profil kesehatan Provinsi Nusa Tenggara Timur 2017 DBD merupakan kejadian luar biasa/KLB (Dinkes NTT, 2017). Di kota kupang penyakit DBD sering muncul sebagai KLB dengan angka kesakitan dan kematian yang relatif tinggi. Angka kesakitan DBD tahun 2013-2017 mengalami fluktuasi, dimana pada tahun 2013 sebesar 73 kasus, dan meningkat pada tahun 2016 menjadi 94,7 kasus (Dinkes Kota Kupang, 2017). Berdasarkan hasil penelitian terdahulu dengan judul Resistensi Aedes sp. sebagai Vektor Demam Berdarah Dengue (DBD) Terhadap Insektisida Permethrin $0.25 \%$ di Kelurahan Kelapa Lima Kota Kupang menunjukkan Vector DBD asal Kecamatan Kelapa Lima telah resisten terhadap insektisida Permethrin $0.25 \%$ dengan presentasi kematian $8.39 \%$ dan juga telah resisten oleh insektisida Cypermethrin dengan presentasi kematian 28,5\% sehingga tergolong memiliki tingkat resitensi yang tinggi. hal ini menjadi salah satu alasan insektisida alami yang mulai dilirik sebagai alternatif penghambat serangga penyakit vector.

Beberapa penelitian menyatakan bahwa pemberian ekstrak daun jeruk purut berpengaruh nyata terhadap mortalitas Culex sp instar III (Novera et al., 2017). Insektisida yang lebih efektif dalam mengakibatkan mortalitas pada nyamuk yaitu insektisida kombinasi serai dan daun zodiac (Boesri et al., 2015; Mahmudi et al., 2019). Efektivitas mat serai wangi (Cymbopogon nardus) sebagai anti nyamuk alami elektrik terhadap nyamuk Aedes aegypti pada dosis $1000 \mathrm{mg}$ (Rahmawati et al., 2020). Jadi, penggunaan bahan-bahan alami selain aman bagi lingkungan juga efektif dalam mengurangi populasi serangga pembawa penyakit menular. Di Indonesia khususnya Provinsi NTT terdapat banyak tumbuhan yang memiliki bahan aktif sebagai insektisida nabati atau alami. Salah satunya yaitu temulawak.

Temulawak adalah tanaman yang mengandung berbagai macam bahan aktif seperti minyak atsiri, kurkuminoid, germacrene, xantorhizol, Alpha- Betha- curcumena, flavonoid 
dan saponin yang dapat menyebabakan gangguan pada sistem pernapasan dan pencernaan larva hingga mengalami kematian sehingga dapat di manfaatkan sebagai larvasida alami(Berri et al., 2020; Dermawaty, 2015). Dengan adanya ektrak temulawak aka mampu memutus mata rantai penularan penularan penyakit DBD. Sehingga menjadi alasan pengabdian yang bertujuan untuk Pelatihan Pemamfaatan Pestisida Alami Berbahan lokal untuk Pencegahan Vektor Demam Berdarah Dengue (DBD) di Kelurahan Kelapa Lima Kota Kupang ini dilakukan.

\section{Materials and Methods}

Metode yang digunakan dalam kegiatan pengabdian kali ini adalah action research melaui penyuluhan, pelatihan, dan mengolah bahan alami yang berada di sekitar halaman rumah sebagai bahan anti nyamuk penyebab DBD serta pendampingan secara langsung di lapangan. Adapun metode demonstrasi/pelatihan, penyuluhan, penerapan dan partisipasi dari mitra dalam pelaksanaan kegiatan, tahap persiapan yang meliputi kegiatan perencanaan, perancangan desain, survei dan sosialisasi kegiatan pada aparatur desa, tokoh masyarakat dan kelompok ternak serta persiapan bahan; Tahap pelaksanaan. Kegiatan yang dilakukan adalah melakukan penyuluhan, melakukan pelatihan dan mengolah bahan alami yang berada di sekitar halaman rumah sebagai bahan anti nyamuk. Kegiatan pendampingan masyarakat dan monitoring secara berkelanjutan. Pengumpulan data dilakukan dengan cara survei dan observasi langsung di lokasi kegiatan. Analisis data dilakukan dengan mengolah data hasil survei dan observasi kegiatan di lokasi pengabdian dan didiskusikan oleh Tim Pelaksana. Lokasi kegiatan pengabdian ini dilaksanakan di Kelurahan Kelapa Lima Kota Kupang.

\section{Results and Discussion}

Kegiatan pengabdian diawali dengan koordinasi tim pelaksana, selanjutnya dilakukan penyuluhan sosialisasi dan koordinasi dengan kelompok mitra. Kegiatan penyuluhan dilakukan di rumah Bapak Fransikus Edy selaku Sekretaris Rukun Tetangga di kelurahan kelapa Lima RT/Rw 27/12. Berikut adalah rincian materi penyuluhan yaitu Arti Penting DBD Dan Bahaya Yang Ditimbulkan, Resistensi Insektisida Vektor penyebab DBD, Ragam jenis tanaman yang berpotensi sebagai anti nyamuk vector DBD. Kegiatan pengabdian ini ditunjukkan pada gambar 1 .
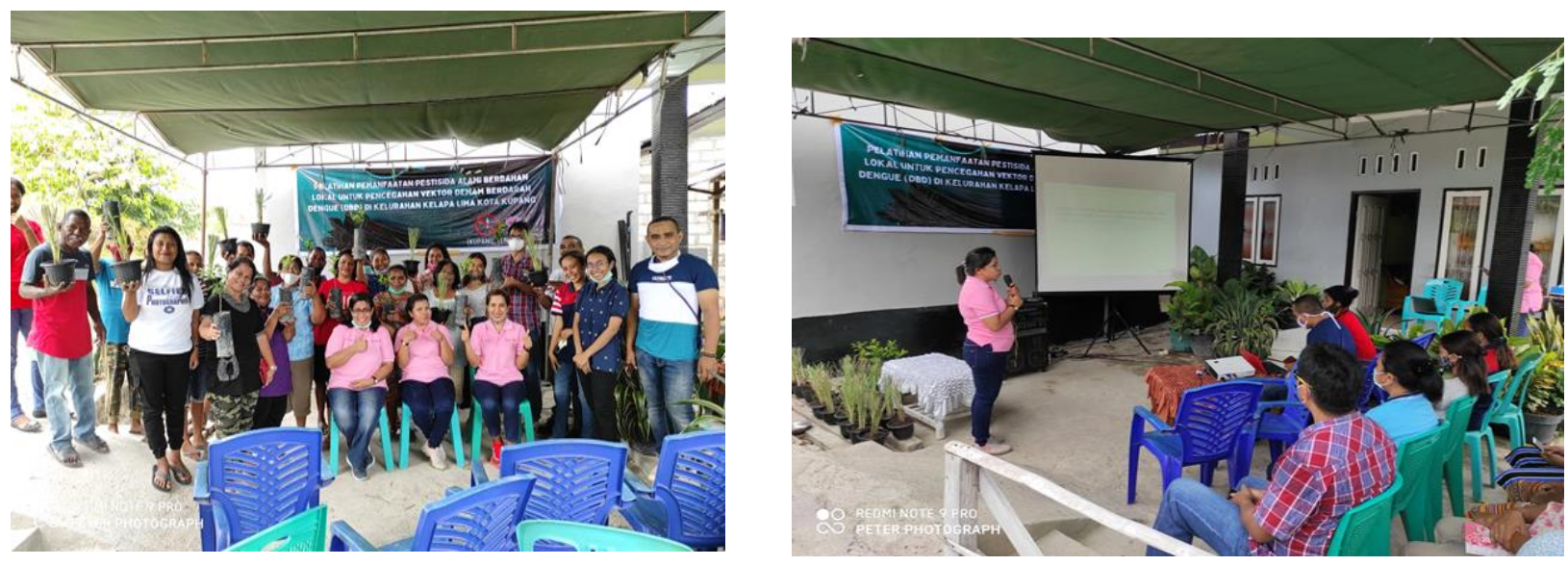

Gambar 1. Sosialisasi kegiatan oleh tim pengabdian.

Masyarakat sangat antusias dengan kegiatan penyuluhan ini. karena merupakan informasi dan ilmu yang sangat bermanfaat dan juga dapat membantu menentukan langkahlangkah pencegahan penyakit Demam Berdarah dengue dilingkunganya dengan 
menggunakan tanaman-tanaman di pekarangan sebagai anti-nyamuk. Kegiatan dilanjutkan dengan penyerahan jenis tanaman yang berpotensi sebagai anti nyamuk kepada masyarakat/peserta pengabdian untuk selanjutnya dapat di tanam di sekitar rumah atau tempat tinggal warga yang nantinya dapat diolah atau digunakan untuk meminimalkan perkembangbiakan nyamuk sebagai vector Demam Berdarah dengue.

Kegiatan pengabdian ini sangat memberikan pengetahuan kepada masyarakat, hal ini tidak terlpeas darai metode yang digunakan. Dalam pengabdian ini masyarakat dilatih, di damping dalam membuat dan menerapakan insektisida yang digunakan. Adanya pelaihan dan penuluhan akan membantu masyarakat untuk lebih paham akan materi yang dilatihakan. Pelatihan adalah proses di mana orang-orang mencapai kemampuan tertentu untuk membantu mencapai tujuan organisasi. Perubahan yang paling jelas dalam pelatihan dan pengembangan adalah pergeseran untuk peningkatan kinerja dan penggunaan teknologi. Dengan demikian, keterampilan, pengetahuan dan kemampuan semakin diperlukan dalam pelaksanaan pelatihan dan pengembangan SDM (Sulaefi, 2017). Pemberian pelatihan dan pendampingan adalah salah satu solusi yang bisa diberikan pengetahuan yang lebih baik kepada masyarakat berkaitan dengan penyakit menular vector serta insektisida alami yang digunakan.

Dari pelatihan ini masyarakat dikenalkan beberapa tanaman yang ada disekitar rumah yang bisa dugunakan sebagai salah satu insektisida alami yaitu temulawak. Temulawak adalah tanaman yang mengandung berbagai macam bahan aktif seperti minyak atsiri, kurkuminoid, germacrene, xantorhizol, Alpha- Betha- curcumena, flavonoid dan saponin yang dapat menyebabakan gangguan pada sistem pernapasan dan pencernaan larva hingga mengalami kematian sehingga dapat di manfaatkan sebagai larvasida alami (Berri et al., 2020; Dermawaty, 2015). Dengan adanya ektrak temulawak aka mampu memutus mata rantai penularan penularan penyakit DBD. Selain temulawak beberapa tanaman yang ada dlingkungan yang bisa digunakan adalah serai wangi. Pemberian ekstrak daun jeruk purut berpengaruh nyata terhadap mortalitas Culex sp instar III (Novera et al., 2017). Insektisida yang lebih efektif dalam mengakibatkan mortalitas pada nyamuk yaitu insektisida kombinasi serai dan daun zodiac (Boesri et al., 2015; Mahmudi et al., 2019). Efektivitas mat serai wangi (Cymbopogon nardus) sebagai anti nyamuk alami elektrik terhadap nyamuk Aedes aegypti pada dosis $1000 \mathrm{mg}$ (Rahmawati et al., 2020). Jadi, penggunaan bahan-bahan alami selain aman bagi lingkungan juga efektif dalam mengurangi populasi serangga pembawa penyakit menular. Jadi, dengan masyarakat tahu banyak bahan alami yang bisa digunakan sebagai insektisida akan secara langsung dapat mengurangi pencemaran dan kerusakan lingkungan akaibat insektisida dari bahan kimia.

\section{Conclusion}

Peningkatan pengetahuan pemahaman masyarakat tentang penyakit DBD serta bahaya yang ditimbulkan, Peningkatan pemahaman masyarakat tentang bio ekologi vector penyebab DBD, Meningkatkan pemahaman masyarakat tentang tanaman-tanaman yang berpotensi sebagai anti nyamuk, dan Mitra mampu mengolah dan memiliki tanaman -tanaman /bahan dari alam sebagai anti nyamuk.

\section{Acknowledgement}

Kami mengucapkan terima kasih kepada Universitas Nusa Cendana yang telah menyetujui dan mendanai pelaksanaan Kegiatan Pengabdian Kepada Masyarakat di Kelurahan Kelapa Lima Kota Kupang.

\section{References}

Almet, J., Wuri, D. A., Detha, A. I. R., \& Lanasakti, T. D. (2019). Status Resistensi Vektor Filariasis Terhadap Insektisida Bendiocarb Asal Kabupaten Sumba Barat Daya. 
Prosiding Seminar Nasional VII Fakultas Kedokteran Hewan Universitas Nusa Cendana Swiss, 427, 66-85.

Almet, J., Wuri, D. A., Detha, A. I. R., \& Mogi, D. A. (2020). Status Resistensi Vektor Filariasis Asal Kabupaten Sikka Terhadap Insektisida Permethrin. Jurnal Kajian Veteriner, 7(2), 121-127. https://doi.org/10.35508/jkv.v7i2.05.

Ashepet, M. G., Jacobs, L., Van Oudheusden, M., \& Huyse, T. (2021). Wicked Solution for Wicked Problems: Citizen Science for Vector-Borne Disease Control in Africa. Trends in Parasitology, 37(2), 93-96. https://doi.org/10.1016/j.pt.2020.10.004.

Berri, D. W. S., Almet, J., \& Wuri, D. A. (2020). Aktivitas Ekstrak Rimpang Temulawak (Curcuma Xanthorrhiza Roxb.) Sebagai Larvasida Terhadap Aedes Aegypti Di Kecamatan Kelapa Lima Kota Kupang. Jurnal Kajian Veteriner, 8(1), 39-42.

Boesri, H., Heriyanto, B., Susanti, L., \& Handayani, S. W. (2015). Uji Repelen (Daya Tolak) Beberapa Ekstrak Tumbuhan Terhadap Gigitan Nyamuk Aedes Aegypti Vektor Demam Berdarah Dengue The Repellency Some Of Extract Plants Against Aedes Aegypti Mosquitoes Vector Of Dengue Fever. Neliti.Com, 79-85. https://www.neliti.com/publications/127121/uji-repelen-daya-tolak-beberapa-ekstraktumbuhan-terhadap-gigitan-nyamuk-aedes-a.

Braks, M., Medlock, J. M., Hubalek, Z., Hjertqvist, M., Perrin, Y., Lancelot, R., Duchyene, E., Hendrickx, G., Stroo, A., Heyman, P., \& Sprong, H. (2014). Vector-borne disease intelligence: Strategies to deal with disease burden and threats. Frontiers in Public Health, 2(DEC). https://doi.org/10.3389/fpubh.2014.00280.

Dell, A. I., Pawar, S., \& Savage, V. M. (2011). Systematic variation in the temperature dependence of physiological and ecological traits. Proceedings of the National Academy of Sciences of the United States of America, 108(26), 10591-10596. https://doi.org/10.1073/pnas.1015178108.

Dermawaty, D. . (2015). Potential Extract Curcuma ( Curcuma Xanthorrizal Roxb ) As Antibacterials Sub-divisi Rimpang Temulawak ( Curcuma Xanthorrizal Roxb). Artikel Review, 4(1), 5-11. https://juke.kedokteran.unila.ac.id/index.php/majority/article/download/494/495.

Detha, A. (2014). Identifikasi Coxiella brunetii Menggunakan Pengujian Polymerase Chain Reaction pada Kambing Di Kota Kupang. Jurnal Kajian Veteriner, 2(1), 103-110. https://ejurnal.undana.ac.id/JKV/article/view/992.

Detha, A. I. R., \& L., F. A. (2016). The Important Zoonoses in East Nusa Tenggara. 1st ICGH International Conference on Global Health 2016, 1(October), 23. icgh2016.ui.ac.id/wp-content/uploads/2017/01/Abstract-book-ICGH-2016.pdf.

Detha, A. I. R., Wuri, D. A., Almet, J., Riwu, Y., \& Melky, C. (2018). First report of Anisakis sp. in Epinephelus sp. in East Indonesia. Journal of Advanced Veterinary and Animal Research, 5(1), 88-92. https://doi.org/10.5455/javar.2018.e241.

Detha, A., Wuri, D. A., \& Santhia, K. (2015). Seroprevalence of Japanese encephalitis virus using competitive enzyme linked immunosorbent assay (C-ELISA) in pigs in East Sumba, Indonesia. Journal of Advanced Veterinary and Animal Research, 2(4), 481483. https://doi.org/10.5455/javar.2015.b112.

Dillon, J., Stevenson, R. B., \& Wals, A. E. J. (2016). Introduction to the special section Moving from Citizen to Civic Science to Address Wicked Conservation Problems. Conservation Biology, 30(3), 450-455. https://doi.org/10.1111/cobi.12689.

Fuadzy, H., \& Yanuar, F. (2018). Penggunaan Insektisida Komersial dalam Pengendalian Vektor Demam Berdarah Dengue di Provinsi Riau. Balaba: Jurnal Litbang Pengendalian Penyakit Bersumber Binatang Banjarnegara, 14(2), 107-116. https://doi.org/10.22435/blb.v14i2.421. 
Karuppusamy, B., Sarma, D. K., Lalmalsawma, P., Pautu, L., Karmodiya, K., \& Balabaskaran Nina, P. (2021). Effect of climate change and deforestation on vector borne diseases in the North-Eastern Indian State of Mizoram bordering Myanmar. The Journal of Climate Change and Health, 2, 100015. https://doi.org/10.1016/j.joclim.2021.100015.

Liu, Z., Zhang, Z., Lai, Z., Zhou, T., Jia, Z., Gu, J., Wu, K., \& Chen, X. G. (2017). Temperature increase enhances Aedes albopictus competence to transmit dengue virus. Frontiers in Microbiology, 8(DEC), 1-7. https://doi.org/10.3389/fmicb.2017.02337.

Mahmudi, M., Santoso, H., \& Laili, S. (2019). Uji Insektisida Serai (Cymbopogon nardus) dan Daun Zodia (Evodia Suaveolens) Terhadap Mortalitas Nyamuk (Aedes aegypti). Jurnal SAINS ALAMI (Known Nature), 2(1), 44-49. https://doi.org/10.33474/j.sa.v2i1.3741.

Novera, R., Hasanuddin, \& Safrida. (2017). Pemanfaatan Ekstrak Daun Jeruk Purut (Citrus Hystrix) Sebagai Insektisida Alami Pembasmi Larva Instar III Culex sp. Jurnal Ilmiah Mahasiswa Fakultas Keguruan Dan Ilmu Pendidikan Unsyiah, 2(1), 31-39. http://www.jim.unsyiah.ac.id/pendidikan-biologi/article/view/2126/2365.

Paaijmans, K. P., Blanford, S., Chan, B. H. K., \& Thomas, M. B. (2012). Warmer temperatures reduce the vectorial capacity of malaria mosquitoes. Biology Letters, 8(3), 465-468. https://doi.org/10.1098/rsbl.2011.1075.

Rahmawati, U., Gustina, M., \& Mirza, R. (2020). Efektivitas Anti Nyamuk Alami Elektrik Mat Serai Wangi (Cymbopogon Nardus) Dalam Mematikan Nyamuk Aedes Aegypti. Journal of Nursing and Public Health, 8(2), 100-107. https://doi.org/10.37676/jnph.v8i2.1207.

Sulaefi, S. (2017). Pengaruh Pelatihan Dan Pengembangan Terhadap Disiplin Kerja Dan Kinerja Karyawan. Jurnal Manajemen Dan Kewirausahaan, 5(1). https://doi.org/10.26905/jmdk.v5i1.1212.

Sutarto, \& Syani, A. Y. (2018). Insecticide Resistance in Aedes aegypti. J Agromedicine, $5(2)$, $582-586$. https://juke.kedokteran.unila.ac.id/index.php/agro/article/download/2130/pdf.

Tamonob, M. P. A., Detha, A. I. R., \& Wuri, D. A. (2019). Deteksi sistiserkosis pada babi yang dipotong di Rumah Potong Hewan Kota So'e. Jurnal Veteriner Nusantara, 2(2), $1-9$. 